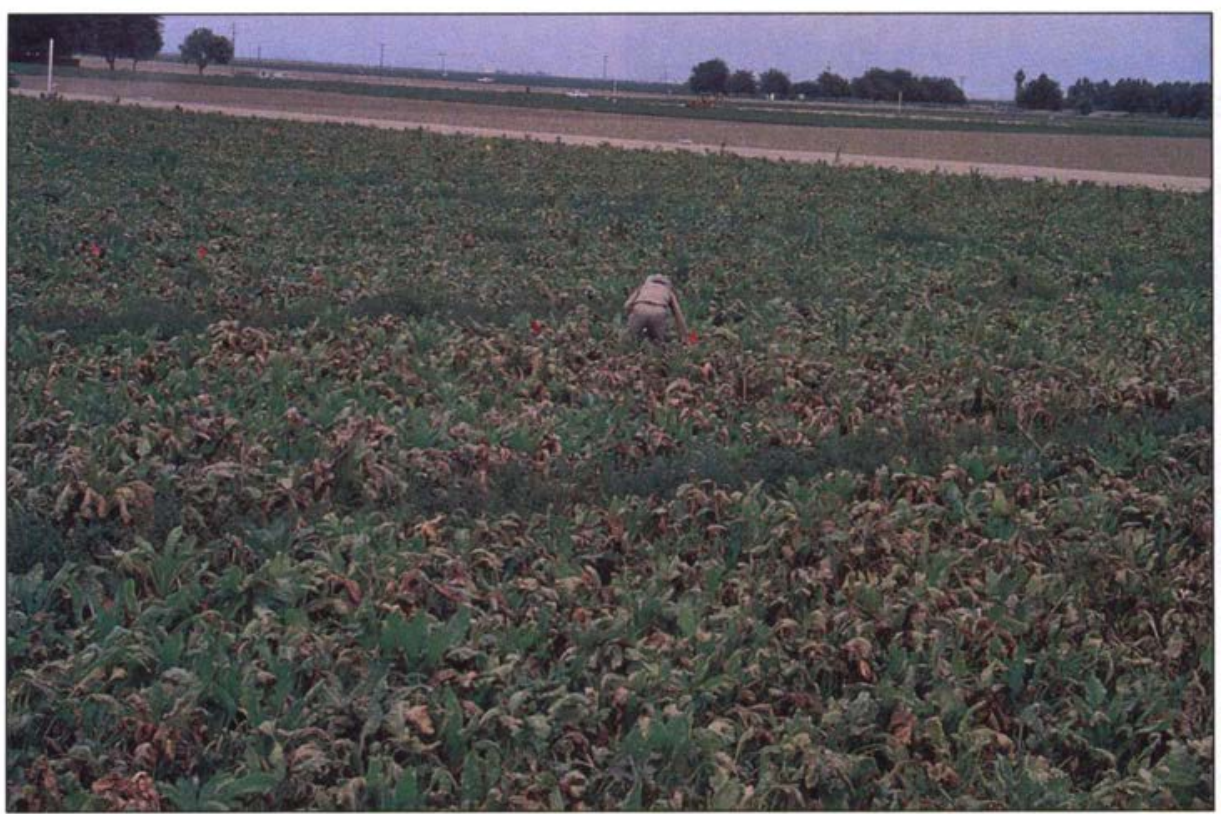

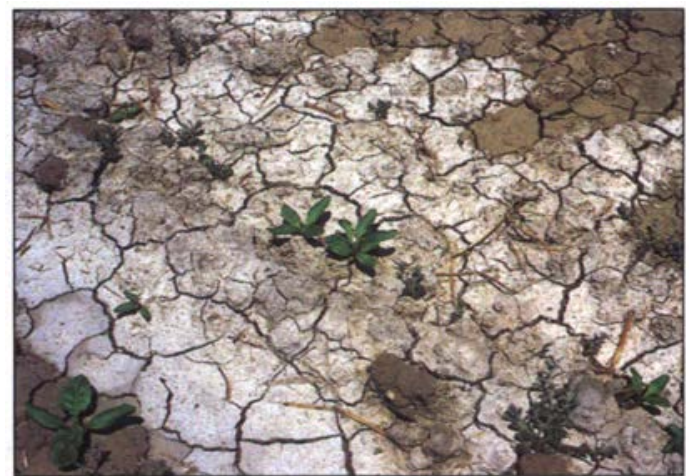

$\Delta$ Without a drainage outlet to the sea, salts will continue to accumulate in the soils and shallow groundwater of the San Joaquin Valley.

4 Soil moisture measurements being made in one of the $\mathbf{4 0}$ plots in Field 41 at the Westside Research and Extension Center.

\title{
Saline water can be reused to irrigate sugarbeets, but sugar may be low
}

\section{Stephen Kaffka \\ 口 Dong Daxue \\ $\square$}

\begin{abstract}
Salt is currently being transported into the San Joaquin Valley via rivers and irrigation water at about three times the rate that it is being removed, endangering the productivity of agricultural land. As a possible salt-management solution, the San Joaquin Valley Drainage Implementation Program seeks to reuse saline water, such as tile drainage water or shallow well water, in crop production.
\end{abstract} Sugarbeet is a deep-rooted, salttolerant crop that can be used as part of a cyclic reuse program to reduce drainage-water volume and conserve high-quality water. Although sugarbeets grown with saline water produced adequate yields on test plots, sugar percentages declined because nitrogen also was present in the irrigation water source. For this reason, irrigating sugarbeets with alternative water sources is more complex, requiring accounting of nitrogen in reused water together with soil nitrogen to assure adequate crop quality.
The amount of salt transported into the San Joaquin Valley via rivers and irrigation water is estimated at 1.86 million tons per day (Alemi 1998). The amount transported out of the valley in the San Joaquin River is approximately $30 \%$ of the amount brought in, or 600,000 tons per day. Over time, this negative balance will cause increasing amounts of productive agricultural land to become saline. To maintain the productivity of one of the world's best farming regions, some means must be found to manage the surplus salts accumulating in valley soils. Otherwise, the state's economy will lose hundreds of millions of dollars, and the world as a whole will lose one of its most valuable and efficient food-producing regions.

Simply draining soils and returning the salts in drainage water to the ocean via the San Joaquin River is problematic because ecologically significant amounts of selenium and other trace elements might potentially harm estuarine systems in the San Francisco Bay and Delta. Ocean disposal will likely be necessary in the long term, but until the disposal problem is better understood a number of in-valley solutions have been proposed, including the reuse of subsurface tile drain water from farm fields and the use of water from shallow wells.

Reusing tile drain water reduces the volume of saline water that must be disposed, while using shallow well water lowers local water tables, keeping the crop root zone from becoming too saline for crop production. Both types of water have elevated salt contents and may also contain nitrogen (N). If drain and shallow well water is moderately to very saline ( $>4.0$ deciSiemens per meter), salt-tolerant crops may be grown. Sometimes, saline water is blended with low-salinity water and then reused. Depending on the amount of blending, the resulting water may be used for a wider range of crops. None of these alternatives, however, significantly reduces the amount of salt accumulating in the San Joaquin Valley.

\section{Salt-tolerant crops}

Several field crops commonly grown in the San Joaquin Valley are moderately to very tolerant of salinity, 


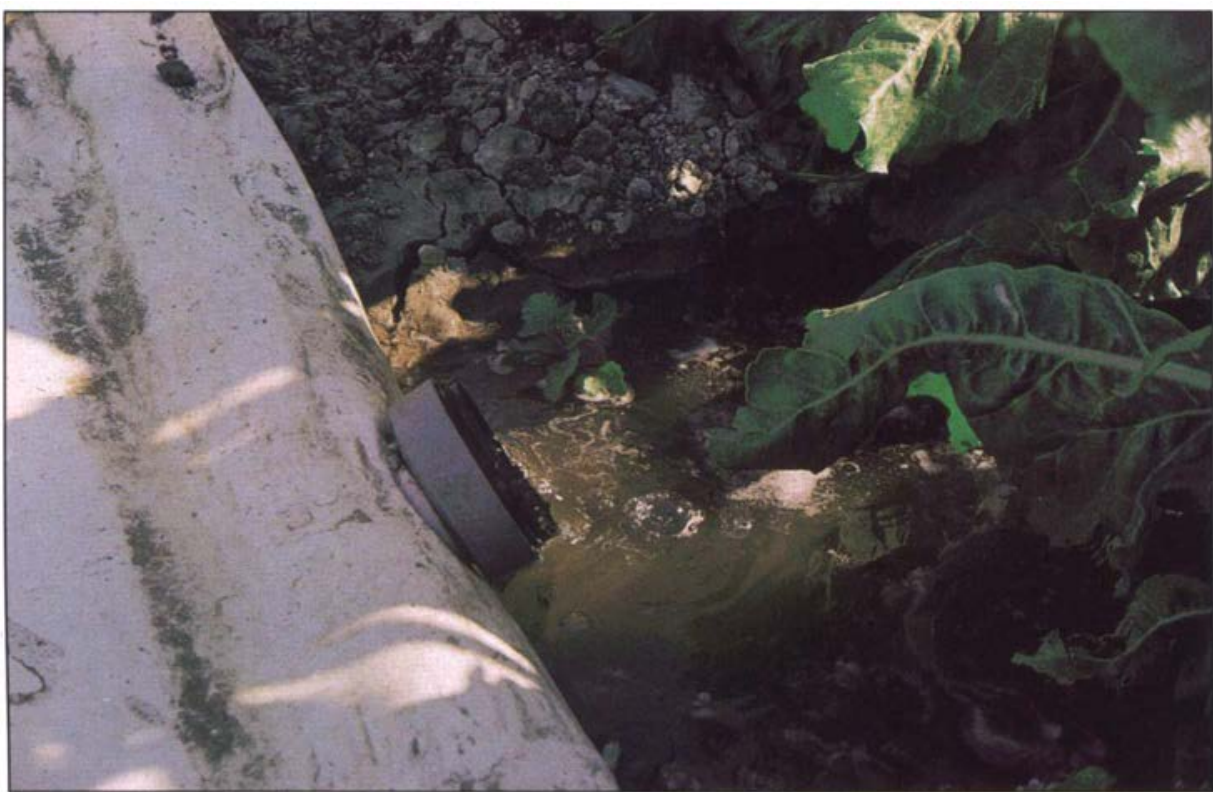

Saline well water being applied to sugarbeet plots. Salt precipitation on the soil surface can be observed.

including safflower, sugarbeet, wheat, barley and cotton. Sugarbeet is also highly tolerant of boron, a common trace element that can be toxic to some crops when present in amounts greater than 2 to $4 \mathrm{mg} / \mathrm{kg}$ (Hanson et al. 1993). Sugarbeet also is efficient at taking up soil $\mathrm{N}$ (Hills 1983). Wheat, barley and sugarbeet are produced during the winter when evaporative demand is low. Salt acts as a stress factor by reducing the amount of available water in the soil profile. The adverse effects of salt on crops grown during the winter are fewer because crop water requirements are much lower.

Studies have been conducted in the Imperial and San Joaquin valleys evaluating the growth of diverse crops, including sugarbeet, when irrigated in part with saline water (Ayars et al. 1990; Rhoades et al. 1988). In general, these studies have shown that sugarbeet tolerates moderate salinity in irrigation water $(4 \mathrm{dS} / \mathrm{m}$ to $8 \mathrm{dS}$ /

TABLE 1. Irrigation water quality

\begin{tabular}{lcc}
\hline \hline & CVP* & Shallow well $\dagger$ \\
\hline $\mathrm{pH}$ & 7.6 & 7.5 \\
$\mathrm{EC}_{\mathrm{w}}(\mathrm{dS} / \mathrm{m})$ & 0.44 & $6.7(0.3)$ \\
$\mathrm{NO}_{3}-\mathrm{N}(\mathrm{ppm})$ & $<0.5$ & $25.6(1.6)$ \\
boron $(\mathrm{ppm})$ & trace & $5.9(0.3)$
\end{tabular}

"CVP: water taken from the Central Valley Project, derived largely from the Sacramento River, a highquality source.

†Well water was taken from a nearby well pumping water from approximately 60 feet in depth. Numbers in ( ) are standard deviations. $m)$. The sugar content of the roots was affected by nitrogen also present in the water, but results were not consistent. Previous trials were limited to the conditions on the farms where they took place; a wider range of treatments could not be evaluated, making it difficult to formulate general recommendations for crop management.

At the UC Westside Research and Extension Center (WSREC), a field site has been used for 11 years to investigate salt tolerance, particularly involving cotton and processing tomatoes. These plots were differentially irrigated with high-quality Central Valley Project (CVP) water or saline water from a nearby shallow well, representing a range of irrigation treatments from $0 \%$ to approximately $70 \%$ saline water. As a result, average soil-profile salinity contents ( 0 to 9 feet) varied from approximately $1.5 \mathrm{dS} / \mathrm{m}$ to 7.0 $\mathrm{dS} / \mathrm{m}$ during the time of the trial. The WSREC site offered an opportunity to investigate the growth and development of sugarbeet crops under a range of moderate soil and water salinity levels in one location.

During the 1996 to 1997 growing season, these plots were used to evaluate the growth, development and yield of fall-planted sugarbeet exposed to different combinations of soil and irrigation water salinity; to relate yield, crop growth and quality characteristics to irrigation practices, water qual- ity, soil-profile salinity and soil residual $\mathrm{N}$ content; and to measure the amount of water used and the uptake pattern of sugarbeet throughout the season, relating water use to soil and water salinity.

\section{Plots varied in salinity}

Sugarbeets (SSNB7 variety) were planted on Oct. 16, 1996, in 40 plots, 32.5 feet by 140 feet each, and harvested on July 19, 1997. We sampled soils shortly after planting in early November and immediately after harvest in late July. Cores 9 feet deep were collected in 1-foot increments from all the plots and analyzed for electrical conductivity of the saturation paste extracts $\left(E_{\mathrm{e}}\right)$. Electrical conductivity of a soil extract increases with salt content. $\mathrm{EC}_{\mathrm{e}}$ is the most commonly used measurement for soil salinity because it can be quickly and accurately estimated. Twelve plots were equipped with neutron access tubes, two per plot. In plots with neutron access tubes, two cores per plot were collected. These samples were analyzed for $\mathrm{EC}_{\mathrm{e}}$, nitrate nitrogen $\left(\mathrm{NO}_{3}-\mathrm{N}\right)$ and boron Root depth was determined indirectly by inferring root activity from soil-water uptake data measured with a sealed-source neutron probe. We collected water samples at each irrigation for analysis (table 1). Approximately 7.5 tons of salt and 68 pounds of $\mathrm{N}$ were applied per acre-foot of saline irrigation water.

All plots received 100 pounds of $\mathrm{N}$ at planting. Sugarbeets were established and furrow irrigated with nonsaline water in October and November. They were irrigated with either nonsaline or moderately saline water drawn from a nearby shallow well from April to June; irrigation was cut off 4 weeks before harvest. All plots were irrigated at the same frequency.

Starting in spring, different plots were irrigated only with low-salinity CVP water (average $\mathrm{EC}_{\mathrm{w}}=0.4 \mathrm{dS} / \mathrm{m}$ ); some with saline water only (average $\mathrm{EC}_{\mathrm{w}}=6.7 \mathrm{dS} / \mathrm{m}$ ); some with saline water in early spring, followed by low-salinity water in late spring (average $\mathrm{EC}_{\mathrm{w}}=4.2 \mathrm{dS} / \mathrm{m}$ ); and others with low-salinity water in early spring, fol- 
lowed by saline water in late spring (average $\mathrm{EC}_{\mathrm{w}}=3.3 \mathrm{dS} / \mathrm{m}$ ). Different average $\mathrm{EC}_{\mathrm{w}}$ reflected the different proportions of saline water $(0 \%, 100 \%$, $62 \%$ and $49 \%$ ) applied. The well water also contained nitrates (table 1); amounts applied were $2.2,132,84$ and 63 pounds $\mathrm{N}$ per acre, respectively. A few plots that had received large amounts of saline water in previous years were irrigated with CVP water, and $a$ few that had been irrigated primarily with CVP water were irrigated with saline water to observe the effects of reclaiming salinized soils or the effects of first using saline water on previously nonsalinized plots. Results from these plots were compared to adjacent ones receiving opposite irrigation treatments.

We determined plant populations during the growing season and at harvest, while yields were determined by harvesting three 70 -foot rows from the center of each plot. Total biomass, root biomass, percent sucrose, and root so$\operatorname{dium}(\mathrm{Na})$, potassium $(\mathrm{K})$, amino $\mathrm{N}$ and $\mathrm{NO}_{3}-\mathrm{N}$ concentrations were analyzed at harvest, as well as total plant $\mathrm{N}$ in tops and roots. The data was used to calculate recoverable sugar. The Spreckels Sugar Company in Mendota analyzed root quality.

Using a sealed-source neutron device, we monitored consumptive water use by depth in the soil profile throughout the growing season. Crop water use was determined using a soil-water balance equation based on neutron probe data.

$$
\mathrm{ETC}=\mathrm{P}+\mathrm{I}+\mathrm{SWD}-\mathrm{D}
$$

Where ETc = crop evapotranspiration, $\mathrm{P}=$ precipitation, $\mathrm{I}=$ irrigation, $\mathrm{SWD}=$ soil water depletion and $\mathrm{D}=$ drainage.

Volumetric soil moisture content in the deepest soil layers changed very little during the growing season, except near the end of the season when plant roots penetrated the deepest. In calculating crop water use based on the mass balance equation, drainage was set equal to zero.

\section{Differences in water use}

We grouped plots by irrigation treatment, then compared water use and yields. There were no significant differences among the four irrigation treatments in average seasonal water use. While increasing salinity in some treatments did not reduce the overall water use, more water may have been taken up from deeper in the soil profile by plants in saline irrigation plots than in plots receiving CVP water.

Differences in seasonal soil water depletion (SWD), while not a large portion of total water use, indicate that roots were more active deeper in the soil profile in saline irrigation plots (fig. 1). As plots received larger amounts of salts with irrigation, surface soil layers became more saline (fig. 2), perhaps restricting water uptake. A smaller proportion of the available water in the upper soil layers was used by plants in the more saline plots throughout the season, though differences were not always significant (fig. 3). Higher salinity apparently forced plants to recover water from a larger soil volume and from less saline areas.
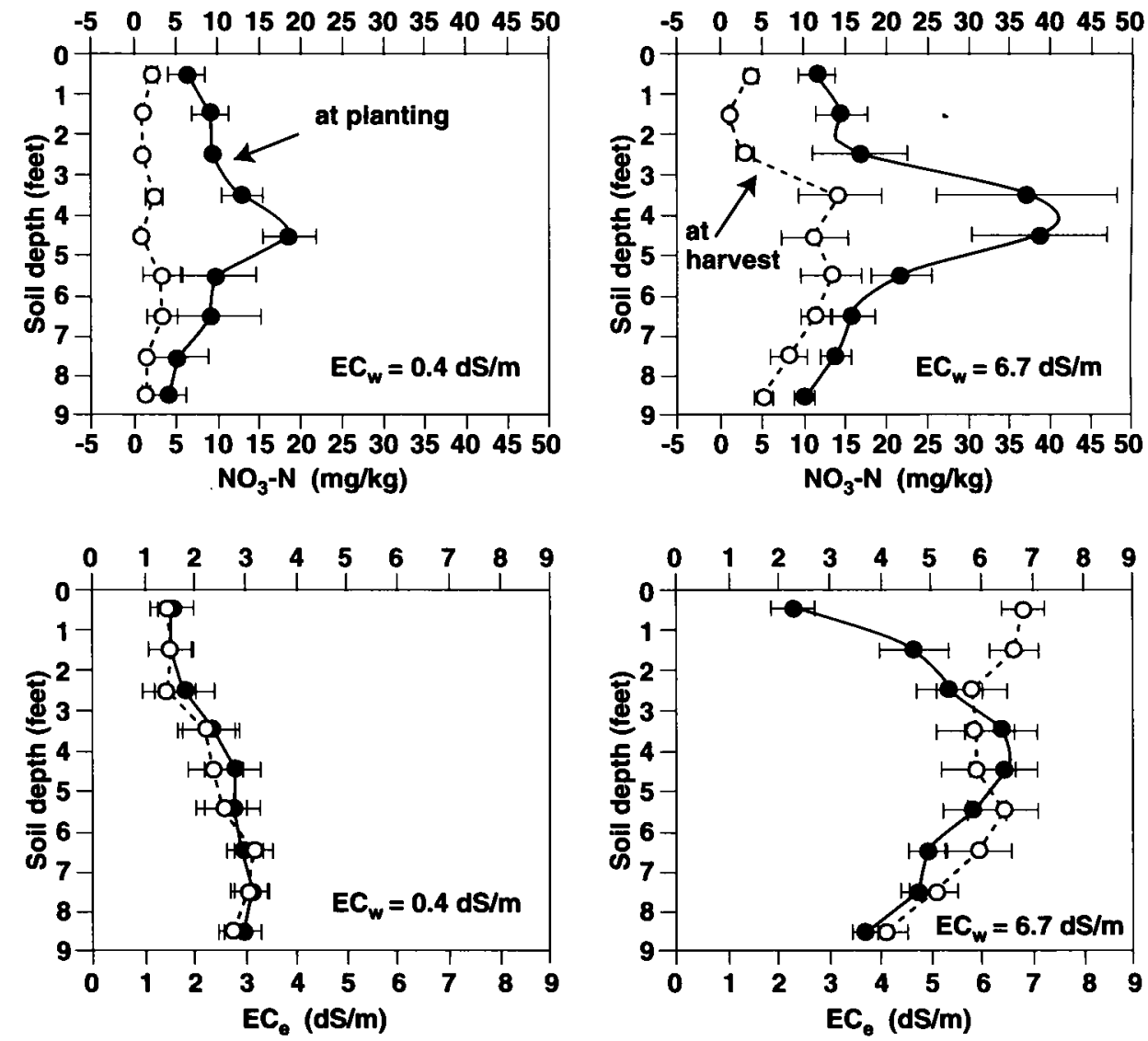

Fig. 2. Soil $\mathrm{NO}_{3}-\mathrm{N}$ and $E C_{0}$ values in plots receiving only saline water $\left(E c_{w}=6.7 \mathrm{dS} / \mathrm{m}\right)$ or CVP water $\left(E c_{w}=0.4 \mathrm{dS} / \mathrm{m}\right)$. The saline irrigation treatments were applied primarily to plots that recelved the most saline water in prior years. 


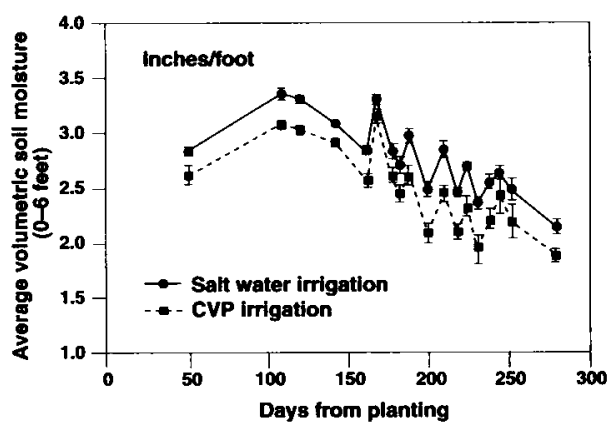

Fig. 3. Average volumetric soil water content ( 0 to 6 feet) in saline and nonsaline CVP-water irrigated plots.

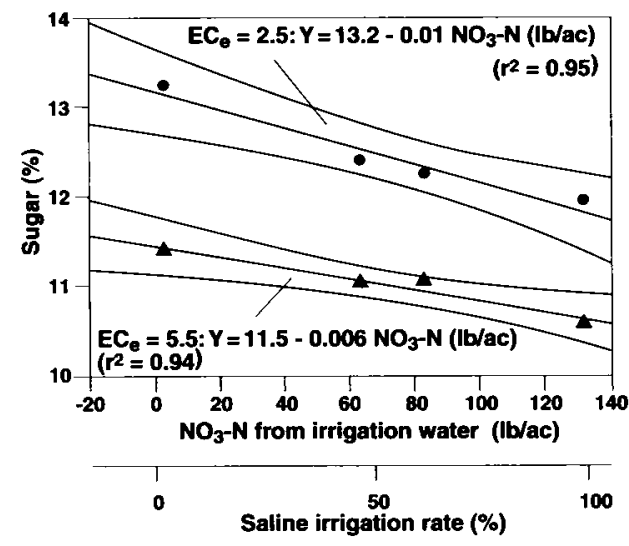

Fig. 4. The decline in sugar yield in relation to the amount of nitrate nitrogen applied with irrigation water. Plots are grouped according to their average profile salinity levels at planting. The application of $N$ in irrigation water to plots with smaller amounts of residual $\mathbf{N}$ caused a greater decline in sugar percent than plots with higher amounts of residual $\mathbf{N}$. Lines are plotted with $95 \%$ confidence intervals.

\section{Crop growth and yields}

Plant populations were stable throughout the trial and were not affected by irrigation treatments (table 2). Root rots were not observed, and there were no measurable differences in leaf area index among irrigation treatments. Sugarbeet root yields, when grouped by the irrigation treatments, were not significantly different from one another (table 2). Sugar percent and gross and recoverable sugar yield, however, declined when the crop was irrigated with saline water.

Even though the sugar concentrations in the roots were higher in plots receiving only CVP water, sugar percentages were low on average, compared to levels thought necessary for good economic returns in California. To yield the highest possible sucrose concentrations in sugarbeet roots, crops are managed to be $\mathrm{N}$ deficient 6 to 8 weeks prior to harvesting. The $\mathrm{N}$ status is determined by the analysis of leaf petioles, which should decline to $1,000 \mathrm{ppm} \mathrm{NO}_{3}-\mathrm{N}$ or less on a drymatter basis. At harvest, the petiole $\mathrm{N}$ level was $4,000 \mathrm{ppm}$ in the CVPirrigated plots, and a few thousand ppm higher in all the other irrigation treatments, suggesting that in all plots, large amounts of residual soil $\mathrm{N}$ were present. The analysis of soil core samples confirmed that large amounts of residual soil $\mathrm{N}$ were present from 4 to 6 feet deep in all the plots (fig. 2). This $\mathrm{N}$ accumulated in large amounts in plots that received large amounts of saline water over time, but also accumulated from normal fertilization and irrigation practices, though in lesser amounts.

In a few plots, irrigation treatments were reversed, with saline water applied to plots with a prior history of irrigation primarily with CVP water, and CVP water applied to plots that had been irrigated predominantly with saline water. Those that received lower-saline water had significantly higher sugar percentages in roots and larger sugar yields (table 3 ). Lower
TABLE 2. Plant population, root and sugar yields at Westside Research \& Extension Center, 1996-97

\begin{tabular}{lccccc}
\hline \hline $\begin{array}{l}\text { Irrigation } \\
\text { treatment }\end{array}$ & Root number & $\begin{array}{c}\text { Clean root } \\
\text { yield* }\end{array}$ & Sugar & Sugar yield & $\begin{array}{c}\text { Recoverable } \\
\text { sugart }\end{array}$ \\
\hline CVP water & plants/ac & tac & $\%$ & lb/ac & lb/ac \\
Saline water & 31,450 & 31.9 & 13.4 & 8530 & 8285 \\
CVP/saline & 31,183 & 32.2 & 11.0 & 7031 & 6748 \\
Saline/CVP & 31,111 & 31.3 & 10.9 & 6844 & 6583 \\
$\mathrm{P}=$ & 32.2 & 11.4 & 7340 & 7065 \\
LSD & 0.927 & 0.80 & 0.0001 & 0.0001 & 0.0001 \\
& $\mathrm{NS}$ & $\mathrm{NS}$ & 0.5 & 500 & 495 \\
\hline "Gross root weight $\times$ tare percentage & & & & \\
†Adjusted for root impurities &
\end{tabular}

root nitrate content was correlated with higher sugar percentage in roots.

Applying low-nitrate CVP water to previously salinized plots (with large amounts of residual $N$ ) did not significantly raise sugar percentages from the overall plot average, whereas applying saline high-nitrate water to unsalinized plots reduced sugar percent compared to the unsalinized treatment (table 3). Sugar yields declined in plots that received saline irrigation water in proportion to the amount of water applied. Because the amount of soil $\mathrm{N}$ in the soil profile was correlated with salinity, sugar yields declined at a greater rate in plots that were initially lower in salinity than in plots that were initially higher in salinity (fig. 4).

\section{Salt and nitrogen management}

The results from this experiment reflect the outcome of a longer-term cyclic reuse strategy for the disposal of saline drainage or shallow well water. Because of the multiyear application of saline water to these plots, both salts and nitrates had accumulated in the soil. These accumulations adversely affected sugar yields in beets, which are sensitive to excess soil nitrogen late in the growing season. Root yields (and total biomass accumulation) were unaffected by the combinations of soil and water salinity experienced by beets in this trial. By harvest, some plots had reached an average salinity (0 to 9 feet), of $8 \mathrm{dS} / \mathrm{m}$, with even higher levels in some upper soil layers. Sugarbeet was able to compensate for this increased salinity, we believe by taking up water from deeper in the soil profile where soils were less saline.

Nitrogen present in drainage and shallow well water confounds the effects of salinity and makes the cyclic reuse of drainage water on sugarbeet or other nitrogen-sensitive crops more complex. The prudent use of recycled water for sugarbeet will depend on the amount of $\mathrm{N}$ present in the water and the amount of residual $N$ present in the crop root zone. This may be deeper than traditionally reported, and deeper than the 3-foot depth used for preplant soil $\mathrm{N}$ testing. Sugarbeet is a deep-rooted crop that grows for ex- 
tended periods of time. In this trial and others conducted at the Westside Research and Extension Center, water was taken up by some beets from 9 feet deep.

This capacity must be taken into account in managing beet crops. If a large amount of $\mathrm{N}$ is present in drainage or well water, it should be used for irrigation as early in the growing season as possible, followed by the use of better-quality water to allow for the depletion of $\mathrm{N}$ by the growing crop 6 weeks prior to harvest. The $\mathrm{N}$ applied with the water also should be used to discount the amount needed as fertilizer. However, if a large amount of $\mathrm{N}$ is present in the soil profile, and the additional $\mathrm{N}$ from irrigation water meets or exceeds the crop's requirements, there may be little the grower can do to achieve a high sugar percentage.

In developing a cyclic reuse strategy, an accounting of both the salts and the nitrogen applied is necessary. For crops like sugarbeet, $N$ accounting is necessary to assure larger sugar percentages. Excessive $\mathrm{N}$ can increase susceptibility to disease or cause lodging (due to weak straw) in wheat and other grain crops. For crops that do not respond adversely to excess $N$, good environmental stewardship still requires that the $\mathrm{N}$ applied with irrigation water be considered a part of the grower's fertilization program.

\section{Saline water may lower sugar yield}

Sugarbeet grew well in response to the moderate salinity levels experi-

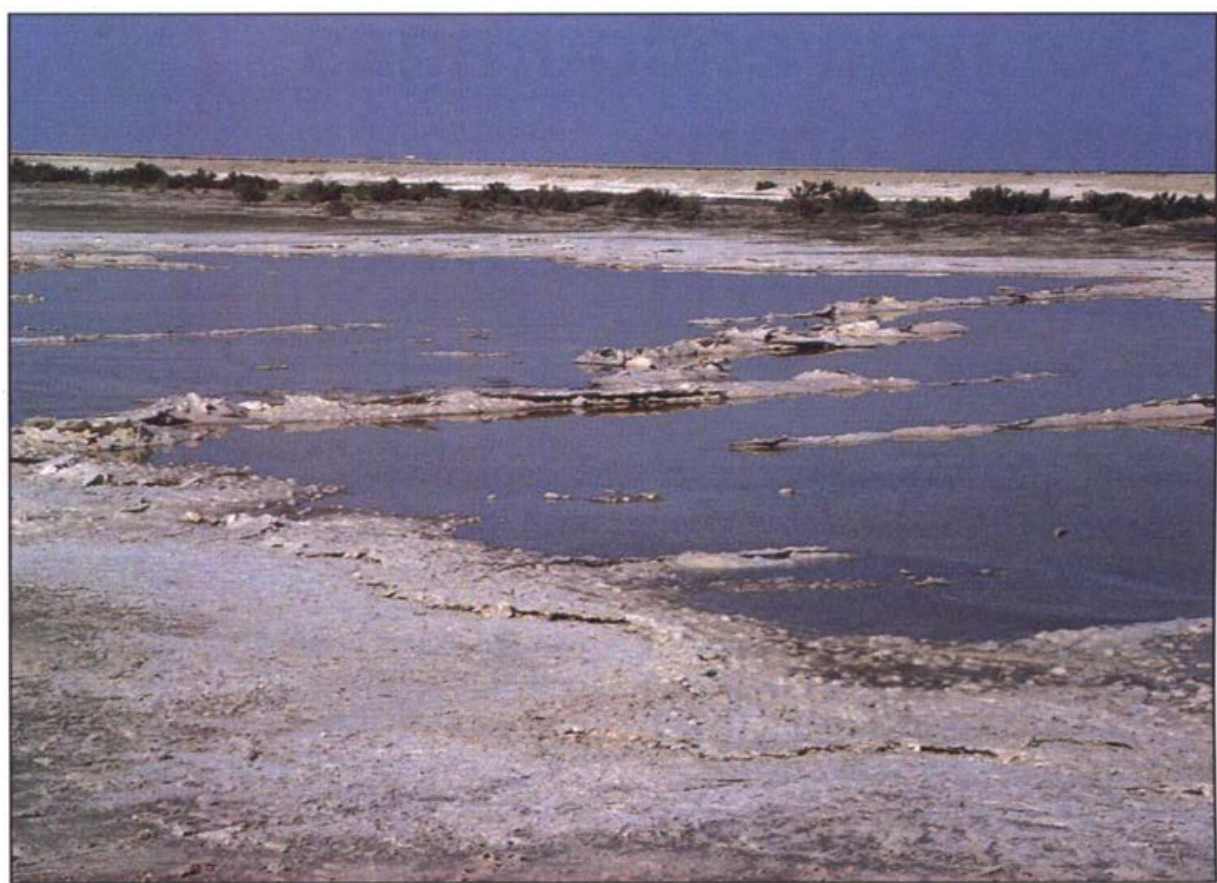

Tulare Lake Drainage District evaporation pond. Reusing drain water reduces the volume of saline water that must be held in evaporation ponds.

enced in this trial, but will suffer reduced sugar yields in the presence of excess nitrogen. Based on estimates from the literature (Hanson et al. 1993), sugarbeet will likely tolerate higher levels of salinity than those observed in this trial, particularly if soils are deep and hold residual soil water at depths not used by other crops, and the soils are not sodic. On deeper soils, sugarbeet seems able to take up water and nitrogen as deep as 9 feet.

The presence of $\mathbf{N}$ in saline drainage water makes the cyclic reuse of such waters on sugarbeet more complex because sugar concentrations may
TABLE 3. Comparisons between adjacent plots receiving contrasting irrigation treatments

\begin{tabular}{|c|c|c|c|c|c|c|c|}
\hline & \multicolumn{5}{|c|}{ Water source } & \multirow[b]{3}{*}{ Plot means } & \multirow[b]{3}{*}{$\begin{array}{c}\text { LSD } \\
(P=0.05)\end{array}$} \\
\hline & \multicolumn{2}{|c|}{$\begin{array}{c}\text { CVP } \\
0.44 \mathrm{dS} / \mathrm{m}\end{array}$} & \multirow{2}{*}{ Plot } & \multicolumn{2}{|c|}{$\begin{array}{c}\text { Shallow well } \\
6.7 \mathrm{dS} / \mathrm{m}\end{array}$} & & \\
\hline & $\begin{array}{c}25 \\
\text { CVP } \\
\text { history }\end{array}$ & $\begin{array}{c}24 \\
\text { Saline } \\
\text { history }\end{array}$ & & $\begin{array}{c}14 \\
\text { CVP } \\
\text { history }\end{array}$ & $\begin{array}{c}15 \\
\text { Saline } \\
\text { history }\end{array}$ & & \\
\hline $\mathrm{EC}_{\mathrm{e}}$ at planting $(\mathrm{dS} / \mathrm{m})$ & 2.8 & 5.5 & & 2.3 & 5.9 & & \\
\hline Clean root yield (tac) & 31.3 & 31.5 & & 33.6 & 36.0 & 31.9 & $\begin{array}{c}3.5 \\
(0.0001)\end{array}$ \\
\hline Sugar $(\%)$ & 14.8 & 11.4 & & 12.0 & 10.6 & 11.7 & $\begin{array}{c}0.96 \\
(0.0001)\end{array}$ \\
\hline Sugar yield (lb/ac) & 9,270 & 7,160 & & 8,030 & 7,610 & 7,436 & $\begin{array}{c}900 \\
(0.0001)\end{array}$ \\
\hline Recoverable sugar $(\%)$ & 97.1 & 95.8 & & 96.2 & 96.0 & 96.3 & $\begin{array}{c}0.5 \\
(0.0001)\end{array}$ \\
\hline Root nitrate (ppm) & 48.7 & 130 & & 102.5 & 125 & 110.1 & $\begin{array}{c}27.3 \\
(0.0001)\end{array}$ \\
\hline
\end{tabular}

be lower than is economically desirable. The prudent use of saline water depends on the amount of $\mathrm{N}$ present in the water and the amount of residual $\mathrm{N}$ and salt present in the soil profile. As much as possible, both $\mathrm{N}$ sources should be taken into account when fertilizing crops.

S. Kaffka is Extension Agronomist, D. Daxue is Visiting Scientist, and G.

Peterson is Staff Research Associate, all in the UC Davis Department of Agronomy and Range Science.

\section{References}

Alemi M. 1998. Drainage Management in the San Joaquin Valley: A Status Report. California Department of Water Resources, San Joaquin Valley Drainage Improvement Program. Sacramento, CA. 65 p.

Ayars JE, Hutmacher RB, Hoffman GJ, et al. 1990. Response of sugarbeet to non-uniform irrigation. Irrig Sci 11:101-9.

Hanson B, Grattan SR, Fulton A. 1993.

Agricultural Salinity and Drainage. Water Management Series pub. No. 93-01. Department of Land, Air, and Water Resources, UC Davis.

Hills FJ, Broadbent FE, Lorenz OA. 1983. Fertilizer nitrogen utilization by corn, tomato, and sugarbeet. Agron J (75):423-6.

Rhoades JD, Bingham FT, Letey J, et al. 1988. Re-use of drainage water for irrigation: Results of Imperial Valley study. Hilgardia 56(5):1-45. 